\title{
Periwinkle Shell as Mixing Ingredient in Concrete: A Review
}

\author{
H. N. Ruslan ${ }^{1}$, K. Muthusamy ${ }^{1}$, S. M. Syed Mohsin ${ }^{1}$ and M. S. Kirgiz² \\ ${ }^{1}$ Faculty of Civil Engineering Technology, Universiti Malaysia Pahang, 26300 Gambang, Pahang, Malaysia \\ 2Department of Civil Engineering, Faculty of Engineering, Istanbul University-Cerrahpasa, 34320 Avcılar/Istanbul, Turkey
}

\begin{abstract}
Growing population which also pushes for rising demand for seafood results in a generation of seashells which are thrown as environmental pollution waste after the edible meat is consumed. Meanwhile, the utilisation of natural resources as mixing ingredients for the production of concrete materials continues to increase over the year. The use of periwinkle shells as mixing ingredients in concrete materials can lower the dependency on natural aggregate supply. This paper discusses the properties of periwinkle shell and method of treatment prior to their usage as a cement and coarse aggregate as well as the mechanical properties of concrete produced using this seashell waste. Overall, the replacement of periwinkle shell as cement and coarse aggregate must be integrated in a specified percentage to enhance the performance of the concrete. For cement replacement, $5 \%$ of replacement gives the highest strength, meanwhile $10 \%$ of replacement as coarse aggregate can meet the desired strength. The increase in the use of periwinkle shell quantity as cement or coarse aggregate replacement reduces concrete workaibility. The integration of periwinkle shell influences the compresssive strength of concrete. Accomplishment in replacing periwinkle shell as cement and coarse aggregate would reduce pollutiion due to shell dumping and save natural resources. However, further investigation in terms of durability properties is recommended.
\end{abstract}

\section{ARTICLE HISTORY}

Received: 31 ${ }^{\text {st }}$ May 2021

Revised: 16th June 2021

Accepted: 10th July 2021

\section{KEYWORDS}

Concrete

Periwinkle shell

Cement

Coarse aggregate

Strength

\section{INTRODUCTION}

Concrete as a building material is the most durable and commonly used material for a wide variety of construction activities [1]. The availability of the mixing ingredients, namely sand, water, granite and raw materials for cement making in many parts of the globe, causes concrete to be easily produced and used everywhere. Concrete is often used for the construction of sustainable bridges, roads, water supply systems, hospitals, residential and industrial buildings to provide people with a social base, a booming economy and useable facilities for many years [2]. The increase in urbanization and the economy has risen the demand for concrete. As of February 2021, 7.8 billion of the total global population are projected [3], and by 2024 new statistics of the world population were estimated at 8 billion and 9.2 billion by 2042 [4]. An expanding human population that requires more building and infrastructure to support their needs causes a larger quantity of concrete need to be produced by harvesting an increasing amount of natural resources to be used as mixing ingredient. The rising harvesting activity of natural resources from the environment, undeniably has a negative impact on the green environment and habitat of wildlife.

Generally, aggregates occupy $70-80 \%$ of the volume of concrete and thus constitute an important role in influencing the performance of concrete [5]. Most industries exploit natural resources such as stones from the mountains for the supply of their raw materials [6]. Therefore, the mining of natural materials for the manufacture of concrete is inevitable [7] and leads to the depletion of natural resources. Mining site morphologies have shown that the mining industry has an impact with the potential to destroy the biodiversity cycle [8]. Other than that, acid mine drainage, land use conversion and habitat loss for humans and animals, noise, dust, blockage effects, erosion, sedimentation and the change in relief are the environmental problems related to mineral aggregate mining [9]. The environmental impact of aggregate mining is most noticeable when land is converted into (temporary) holes in the ground, most frequently from undeveloped or agricultural land usage [10]. Success in using alternative materials made from waste from the industrial trade, agricultural sector, or aquaculture sectors as aggregate replacement in producing concrete would reduce the considerable dependency on natural resources.

Besides that, the manufacturing of concrete and its raw materials also requires a substantial amount of energy and releases a significant footprint of carbon dioxide $\left(\mathrm{CO}_{2}\right)$ to the environment [11]. The cement industry alone has been generating $8 \%$ of the overall anthropogenic carbon dioxide emissions globally [12]. Anthropic climate change might be unavoidable with such enormous amounts of $\mathrm{CO}_{2}$ [13]. Besides that, the cement process also contributes to noise pollution. The primary sources of noise in cement plants are produced by many activities such as blower activity, milling machines and crushers, and electric engines [14]. As a result, conventional concrete is not claimed to be a safe material, since the ingredients used in the composition of concrete are not manufactured in an environmentally friendly way and cause environmental damage [15]. Nevertheless, at present, concrete engineering is moving towards sustainability due to the negative impact on the environment resulting from the reaping of natural resources for concrete production [16]. Thus, 
the option of utilizing recycled products and waste materials has been extensively used as a solution to environmental issues [17].

At the same time, seashells have been one of the waste materials generated in coastal areas and countries that produce significant amounts of seafood [18]. According to FAO [19], 26000 tons of ornamental shells and pearls (USD 179 000) have been produced in 2018. A huge proportion of shells are still discarded as trash, posing a challenge in locations where they have yet to find major usage, with a considerable deposit having been collected in several places over the years [20]. It is because they are generally known as non-degradable material and can contribute to several environmental problems [21]. Seashell waste generates environmental degradation and emissions as a result of both water contamination and landfill management difficulties [22]. The huge amount of shell waste in landfills might cause unpleasant sightings and generate an unpleasant odour [23]. Hou et al. [24] also said that seashell waste can cause contamination of coastal fisheries, public water surface management, a foul smell as a result of decomposure of organics attached to the shells, harm to the natural environment, and health issues. Safi et al. [25] said that one of the most promising utilisations of discarded shells in building materials is the usage in the making of Portland cement or aggregate (coarse aggregates). As a consequence, several researchers conducted investigation on the potential use of seashell debris as materials in concrete.

In addition to environmental issues, using aquaculture waste as materials in concrete can also affect the workability, strength and durability of the concrete. Yang et al. [26] found that crushed oyster shell as fine aggregate in concrete can reduce the workability when the percentage of the replacement increases. Despite that, the strength of concrete containing oyster shell was higher than concrete without substitution (normal concrete) in early age. Olivia et al. [27] has been investigating cockle shell and clam shell as cement replacement in concrete. They found that the density and strength of concrete with substitution of clam shell is higher compared to normal concrete and cockle shell. The believed that the type of seashell used and the amount of $\mathrm{CaO}$ present in the shell influence the physical and mechanical characteristics of concrete. In terms of durability, Yang et al. [28] reported that the use of oyster shell as fine aggregates showed no detrimental effect on freezing and thawing, carbonation, and chemical attack resistance of concrete. In this review, the Periwinkle shell's physical and chemical characteristics were discovered to be the same as natural materials in concrete. The purpose of this review is to analyse the influence of periwinkle shell as cement and coarse aggregate on the workability and compressive strength of concrete. Using seashell waste in concrete may not only affect the strength of the concrete, but it may also help to reduce the use of natural resources in concrete.

\section{Characteristic of Periwinkle in origin condition}

Typically, periwinkle shells may be obtained in rivers or coastal areas. Periwinkles are univalent invertebrates, a relatively cheap source of animal protein belonging to the Phylum Mollusca [29]. Periwinkles shells exist in "V" as a spiral shape, and a circular aperture are small greenish-blue marine snails while in texture it is brittle but very sturdy [30,31]. By constantly attaching the shell to the outside, the mollusc creates this spiral shape, coiling along an imaginary axis passing directly through the shell [32]. The typical winkle has a shell height of $20 \mathrm{~mm}(20-60 \mathrm{~mm}$ in length and 10$20 \mathrm{~mm}$ in diameter) and a life span of three years, but the highest recorded winkle has risen to 52 $\mathrm{mm}$ [33,34]. The appearance of periwinkle shell is shown in Fig. 1.

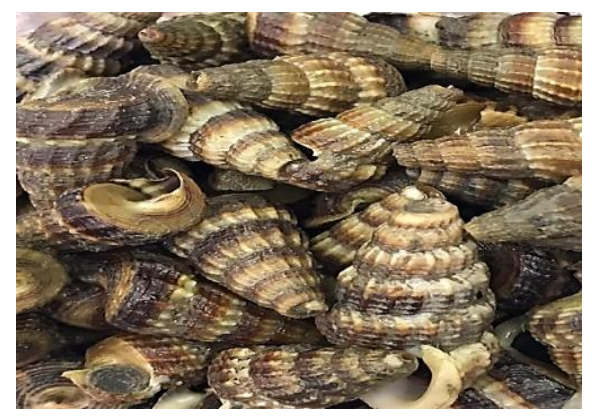

Figure 1. Periwinkle shell

\section{PERIWINKLE SHELL AS CEMENT}

Realization on the degradation of environment due to cement industry, has inspired researchers to use seashell waste materials a cement replacement. Previous researchers, Olutoge et al. [35], Umoh \& Olusola [36], Etim et al. [37], Offiong \& Akpan [38] and Attah et al. [39] has explored the potential use of periwinkle shell as partial cement replacement in concrete. The effect of periwinkle as cement replacement on workability and compresive strength of concrete has been investigated.

\section{Processing method}

Periwinkle which were collected from dumpsite were washed to remove the contaminants and chloride content that can affect the concrete performance [40]. Then, it would be sun dried or open dried for seven day [38] before calcined in 
a furnace. Various temperature has been utilized for calcination process of the shell. Among the temperature that has been used is $600{ }^{\circ} \mathrm{C}[38], 800{ }^{\circ} \mathrm{C}[36,38]$, and $1000^{\circ} \mathrm{C}[39,38,37,35]$. After that, the calcined shell are processed to reduce it size. Then, the periwinkle was brought out from furnace to cool down before ground using grinding machine [35] or hammer and a burr mill [38]. Next, the fine powder is sieved passsing 45um [36.38] and 75um [35,37,39]. The finer the particles of cement, the greater the surface area and the reactivity of their reactions to other substances to form binder with significant strength [18].

\section{Physical and Chemical Properties}

Table 1 and Table 2 summarises the physical and chemical properties of Periwinkle shell ash which used as partial cement replacement. The specific gravity of Periwinkle shell ash is in the range of 0.40 to 2.56. According to Attah et al. [39], periwinkle shell ash has a lower specific gravity than cement, implying that it is lighter. Specific gravity is significant in the construction sector to decide the appropriateness of materials used in concrete manufacturing [41]. The moisture content of Periwinkle shell ash ranged from 1.1 to $1.50(\%)[36,38]$. Other than that, Offiong et al. [38] stated that fineness of periwinkle shell ash (see Fig. 2) is influenced by heat application during calcined proses. They analysed that fineness of periwinkle shell ash calcined at $800{ }^{\circ} \mathrm{C}$ was $62.5 \%$ and $25 \%$ for both periwinkle shell ash calcined at $600{ }^{\circ} \mathrm{C}$ and 1000 ${ }^{\circ} \mathrm{C}$, this show that only periwinkle shell ash calcined at $800{ }^{\circ} \mathrm{C}$ meet the requirement stated by standard where the maximum percentages fineness retained was $34 \%$.

The chemical composition of the shells influence the performance of concrete when it is used as a partial cement substitute [27]. According to their chemical composition, seashells contain all of the major chemical components in Ordinary Portland Cement (OPC) and the ratios are very similar to those of OPC [42]. Seashells contains more than $90 \%$ $\mathrm{CaCO}_{3}$ and when burned to a powdery state, it defined as a calcium oxide $(\mathrm{CaO})$ source [22]. In typical Portland cements, calcium oxide is the major constituent [43]. Even the percentage chemical properties of periwinkle shell ash are lower than that found in OPC, but periwinkle shell ash still comprises the major chemical constituents of cement, which are $\mathrm{CaO}, \mathrm{SiO}_{2}, \mathrm{Al}_{2} \mathrm{O}_{3}$, and $\mathrm{Fe}_{2} \mathrm{O}_{3}$ [35]. Meanwhile, researcheor elsewhere [36, 38] classed this processed periwinkle shell as as pozzolan of class $\mathrm{C}[36,38]$. This is because the silica oxide value of periwinkle shell ash was $42.32 \%$ [39], 33.85\% [38], $29.54 \%$ [37], and 33.84 \% [36]. According to BS EN 197-1: 2009 [44], pozzolan materials must contain 25\% silica oxide in order to be called cementitious composition. On overall, the variation in the chemical composition of periwinkle is shell is influenced by the calcination temparature and grinding technique.

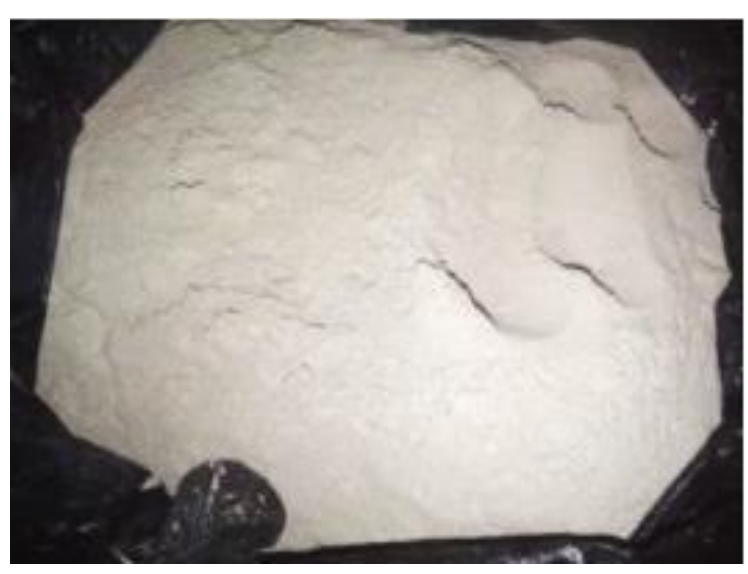

Figure 2. Periwinkle shell ash [45]

Table 1. Physical properties of periwinkle shell ash

\begin{tabular}{lcccc}
\hline & Specific gravity & Bulk density & $\begin{array}{c}\text { Moisture content } \\
(\%)\end{array}$ & Fineness modulus \\
\hline$[35]$ & 2.50 & - & - & - \\
{$[36]$} & 2.13 & - & 1.50 & 3.28 \\
{$[37]$} & 2.56 & - & - & - \\
{$[38]$} & $0.40-1.42$ & $0.39-1.37$ & $1.1-1.5$ & - \\
{$[39]$} & 2.56 & - & - & - \\
\hline
\end{tabular}


Table 2. Chemical properties of periwinkle shell ash

\begin{tabular}{cccccc}
\hline & {$[35]$} & {$[36]$} & {$[37]$} & {$[38]$} & {$[39]$} \\
\hline $\mathrm{CaO}$ & 44.26 & 40.84 & 42.32 & $38.62-46.39$ & 29.54 \\
$\mathrm{MgO}$ & 8.98 & 0.48 & 42.32 & $0.36-0.83$ & 2.32 \\
$\mathrm{~K}_{2} \mathrm{O}$ & 5.90 & 0.14 & 0.11 & $0.13-0.27$ & 0.11 \\
$\mathrm{SiO}_{2}$ & 3.56 & 33.84 & 29.54 & $23.32-33.85$ & 42.32 \\
$\mathrm{SO}_{3}$ & - & 0.26 & 0.31 & $0.15-0.25$ & 0.31 \\
$\mathrm{Na}_{2} \mathrm{O}$ & 1.41 & 0.24 & 0.43 & $0.15-0.27$ & 0.43 \\
$\mathrm{Al}_{2} \mathrm{O}_{3}$ & 2.28 & 10.20 & 11.6 & $9.62-10.84$ & 11.6 \\
$\mathrm{Fe}_{2} \mathrm{O}_{3}$ & 1.75 & 6.02 & 5.13 & $5.01-6.25$ & 5.13 \\
\hline
\end{tabular}

\section{Workability}

Table 3 presents the slump value of concrete containing periwinkle shell ash as partial cement replacement. The slump value of concrete decreases when the percentage replacement of periwinkle shell ash increases. Both researchers, Olutoge et al. [35] and Attah et al. [39] discovered that the concrete slump value decreases as the percentage of periwinkle shell ash used increases from 5\% to 20\%. Umoh \& Olusola, [36] reported that concrete workability reduces when the quantity of the ash used become larger. The slump value of control mix for the studies conducted by Olutoge et al. [35], Attah et al. [39] and Umoh \& Olusola, [36] study was $27.5 \mathrm{~mm}, 29.0 \mathrm{~mm}$ and $29.0 \mathrm{~mm}$ respectively. The higher slump value of mix with periwinkle shell ash at $5 \%$ and $10 \%$ replacement where the value was $26.5 \mathrm{~mm}$ [35], 28.0mm[39] and $28.0 \mathrm{~mm}$ [36] respectively. This shows that concrete with periwinkle shell ash as cement replacement produced low workability as the range of the slump value was between 25 to $75 \mathrm{~mm}$ [46]. The inclusion of periwinkle shell ash does not cause concrete bleeding which can affect the concrete strength. According to Tayeh et al. [18], reduction in workability was due to the uneven form of microlevel seashell particles increasing the surface area. The incorporation of periwinkle shell ash demands more water than ordinary portland cement [37].

Table 3. Workability of conctete with periwinkle shell ash as partial cement replacement

\begin{tabular}{cccc}
\hline & {$[35]$} & {$[36]$} & {$[39]$} \\
\hline Percentage (\%) & \multicolumn{3}{c}{ Slump value $(\mathrm{mm})$} \\
\hline 0 & 27.5 & 29.0 & 29.0 \\
5 & 26.5 & - & 28.0 \\
10 & 24.5 & 28.0 & 25.0 \\
15 & 21.0 & - & 23.0 \\
20 & 16.0 & 28.0 & 21.0 \\
30 & - & 26.0 & - \\
40 & - & 25.0 & - \\
\hline
\end{tabular}

\section{Compressive strength}

The compressive strength of concrete produced using periwinkle shell ash as partial cement replacement has been conducted by past researchers (Fig 3 and Fig 4). Umoh \& Olusola [36] investigated the effect of substituted periwinkle shell ash as cement material on the compressive strength. They observed that concrete replaced with periwinkle shell ash from $0 \%$ to $40 \%$ as partial cement replacement exhibit strength declination as larger ash content is used. The compressive strength at all ages for concrete with $0 \%$ of periwinkle shell ash are higher compared to concrete with $10 \%-40 \%$ of periwinkle shell ash. The utilization of pulverised seashell contains less calcium content $(\mathrm{CaO})$ than cement, disrupts the hydration process, resulting in slower hydration [47] which affect the bearing capacity of concrete. However, the desired strength $\left(25 \mathrm{~N} / \mathrm{mm}^{2}\right)$ has been achieved at ages 28 days, where $10 \%$ substitution of periwinkle shell ash was raised to $25.6 \mathrm{~N} / \mathrm{mm}^{2}$. The results show that the strength increasing when the curing age increase. Yang et al. [28] stated that concrete strength development and/or durability degeneration have happened due to concrete characteristics are generally affected by age. In addition, Razali et al. [48] defined that curing encourages the gradual improvement of the cement hydration process and the formation of calcium silicate hydrate $(\mathrm{C}-\mathrm{S}-\mathrm{H})$ gel, which binds the aggregates to form a rocksolid mass, densifies the concrete, reduces porosity, improves the physical and mechanical properties of concrete. 
Similarly, researcher elsewhere, Olutoge et al. [35], Etim et. al. [37] and Attah et al. [39] also reported the although the concrete compressive strength drops upon integration of periwinkle shell integration, the strength continues to rise as curing age become longer. According to Etim et al. [37], who found that the compressive strength of the control mix was greater than the mix with periwinkle shell ash. The control mix strength values are $19.29,26.31,27.15$, and $28.80 \mathrm{~N} / \mathrm{mm}^{2}$ at $7,14,21$, and 28 days, respectively, while the maximum strength for mix with substitution at $5 \%$ for each age are $18.88,20.56,26.40$, and $26.6 \mathrm{~N} / \mathrm{mm}^{2}$. This is owing to the possible that pozzolanic activity is delayed owing to the likely impact of periwinkle shell ash presence, which leads to a decrease of tri-calcium silicates $\left(\mathrm{C}_{3} \mathrm{~S}\right)$, a generating compound from cement [37]. Although not reactive as cement but periwinkle shell ash behaves like mineral cementitious materials due to its high calcium oxides and silica oxides content [38]. In other hand, further study in durability properties should be conduct such as water absorption, acid resistance and carbonation resistance.

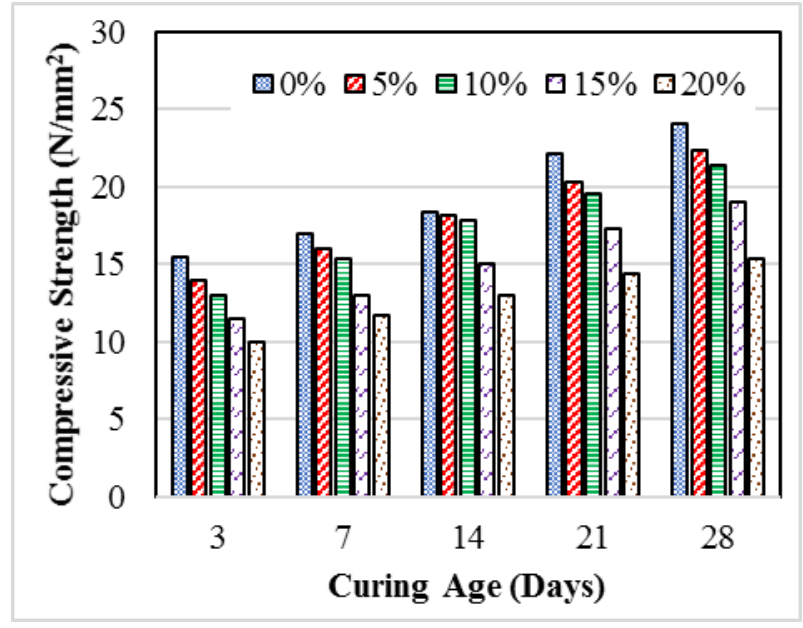

Figure 3. Compressive strength result [35]

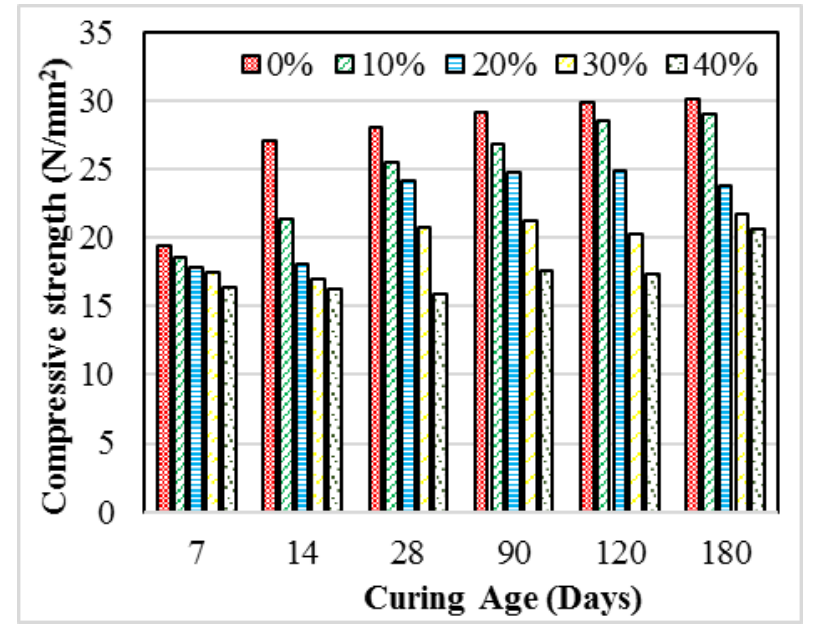

Figure 4. Compressive strength result [36]

\section{PERIWINKLE SHELL AS COARSE AGGREGATE}

The suitability of the Periwinkle as partial or fully coarse aggregate has been investigated by previous researchers. The strength is roughly similar to coarse aggregate might due to considerate of seashell that contains $95 \%$ calcium carbonate [49]. Falade [50], Adewuyi et al. [33], Osarenmwinda and Awaro [51], Falade et al. [52], Ettu et al. [21], Ameh et al. [53], Soneye et al. [54] and Eziefula et al. [55] investigated the properties of concrete containing periwinkle as coarse aggregate replacement. The research was conducted using different mix proportions and various percentages of periwinkle's replacement.

\section{Processing method}

The periwinkles were cleaned with water. The washing phase's purpose is to remove contaminants while limiting the amount of organic matter and chloride ions [56]. Then, it dried for 10 days before being used in concrete under atmospheric conditions [52]. The shells were crushed before used to a required size. Uncrushed seashells should be avoided since their presence might cause voids in the concrete and reduce its compressive strength [57]. Formation of dense concrete with lower amount of voids would be able to produce concrete with satisfactory strength and durability. For the experimental research as a coarse aggregate, particles that kept on a $4.75 \mathrm{~mm}$ sieve were used, while $4.75 \mathrm{~mm}$ sieve particles were omitted [55].

\section{Physical properties}

Table 4 presents some of the physical properties of Periwinkle shell aggregate, which used as a coarse aggregate replacement in concrete making. The size of periwinkle shells as coarse aggregate from the range of 5 to $25 \mathrm{~mm}$. In previous research it was identified that the bulk density of Periwinkle shell aggregate to be $517 \mathrm{~kg} / \mathrm{m}^{3}, 619.90 \mathrm{~kg} / \mathrm{m}^{3}$, and $1243 \mathrm{~kg} / \mathrm{m}^{3}$. Besides that, based on a few studies, specific gravities of Periwinkle shell aggregate were found to be 1.73 , 2.05 and 2.30 respectively. This shows that the specific gravity of the periwinkle shell is less than normal aggregate. According to Neville and Brooks [58], most natural aggregates are between 2.6 and 2.7 of specific gravity. Similarly to the findings of Eziefula et al. [59], they stated that many seashells have equal or slightly lower bulk density and specific gravity relative to the standard aggregates. According to Dahiru et al. [30], since the specific gravity is low, it means that more of these components are needed for concrete manufacture. The researchers observed that the moisture content of periwinkle shell aggregate is in the range of 0 to $11.65 \%$. Based on ASTM C127 [60], the normal-weight aggregates 
absorption and surface moisture is less than $2 \%$. As a result, $11.65 \%$ considered as higher moisture content of aggregate this can lead to reduce strength and durability of concrete.

Table 4. Physical properties of periwinkle shell aggregate

\begin{tabular}{lccccccc}
\hline References & {$[30]$} & {$[33]$} & {$[50]$} & {$[51]$} & {$[52]$} & {$[53]$} & {$[43]$} \\
\hline Size $(\mathrm{mm})$ & $<19.0$ & - & - & - & $6.30-25$ & $5-20$ & - \\
Specific gravity & 1.73 & - & - & 2.05 & - & 2.30 & 2.05 \\
Bulk density $\left(\mathrm{kg} / \mathrm{m}^{3}\right)$ & 619.90 & 1243 & - & 517 & - & - & 660 \\
Dry density $\left(\mathrm{kg} / \mathrm{m}^{3}\right)$ & - & - & - & - & 1353 & - & - \\
Moisture content $(\%)$ & 0 & 1.44 & 8.32 & - & - & 11.65 & - \\
Unit weight $\left(\mathrm{kg} / \mathrm{m}^{3}\right)$ & - & - & 694.44 & - & - & - & - \\
$\begin{array}{l}\text { Absorption capacity } \\
\text { by weight) }\end{array}$ & 25 & - & 12.99 & - & - & - & 4.4 \\
\hline
\end{tabular}

\section{Workability}

The summary of slump value by past researchers is shown in Table 5. Researchers used various percentages of replacement in order to determine the influence of periwinkle shell aggregate on concrete workability. For instance, Falade [50] utilised various percentages for each mix proportion such as $0 \%$ to $50 \%$ for $1: 1 \frac{1}{2}: 3,0 \%$ to $30 \%$ for $1: 2: 4$ and 0\% to 20\% for 1:3:6. However, Adewuyi et. al. [33] and Ameh et. al. [53] The integration of periwinkle shell as coarse aggregate replacement resulted in mix with lower workability [33, 50, 53]. According to Martínez-García et al. [61] reported that an increase in percentage replacement will increase water demand, which results in a reduction in slump value. This was due to several main reasons, namely the irregular particle shape which encourages particle friction, an increased surface area that increases the demand for water and water absorption due to internal voids in seashell waste [16]. The results also present a decreasing slump value when the mix proportion increases. The water/cement (w/c) ratios used were 0.55 [50] for $1: 1 \frac{1}{2}: 3,0.60$ [50,33] for $1: 2: 4,0.80$ [50] 0.55 [33] for 1:3:6 and 0.65 [53] for each mix proportions. It demonstrates that a mix proportion of 1: $1 \frac{1}{2}: 3$ has the greatest slump value, with values ranging from 30 to $2 \mathrm{~mm}$ and 30 to $20 \mathrm{~mm}$, respectively. Meanwhile, a mix proportion of 1:3:6 results in the lowest slump value, with values ranging from 15 to $2 \mathrm{~mm}$ and 10 to $1 \mathrm{~mm}$, respectively. This implies that when the mix ratio increases, the concrete becomes less workable, resulting in a greater demand for water to maintain the same workability level as the control [53]. Besides, according to Shetty [46], this workability is also considered as very low workability as the slump value is near and below $25 \mathrm{~mm}$ and workability determined by compacting factor will be more suitable than slump. On overall, the physical properties of periwinkle which is dissimilar of natural coarse aggregate affects the mix workability when it is used partial coarse aggregate replacement.

Table 5. Workability of periwinkle shell ash as coarse aggregate

\begin{tabular}{cccc}
\hline Researcher & Mix proportion & Periwinkle (\%) & Slump (mm) \\
\hline \multirow{2}{*}[50]{} & $1: 1 \frac{1}{2}: 3$ & $0-50$ & $30-2$ \\
& $1: 2: 4$ & $0-30$ & $13-2$ \\
& $1: 3: 6$ & $0-20$ & $10-1$ \\
{$[33]$} & $1: 2: 4$ & $0-100$ & $18-5$ \\
& $1: 3: 6$ & $0-100$ & $15-2$ \\
& $1: 1 \frac{1}{2}: 3$ & $10-100$ & $30-20$ \\
{$[53]$} & $1: 2: 4$ & $10-100$ & $26-20$ \\
& $1: 3: 7$ & $10-100$ & $25-12$ \\
\hline
\end{tabular}




\section{Compressive strength}

The first investigation on the effect of periwinkle shell as coarse aggregate was conducted by Falade, [50] who reported that the concrete strength decreases when the percentage replacement of periwinkle shell was increased in different concrete mix proportion. This is due to the periwinkle surface which does not encourage a good bond to the granite surface, and the increase in substitution makes the proportion of cement not enough to bind the coarse aggregate effectively. However, the concrete strength continue to develop as curing age become longer. Based on the table, strength of mix proportion 1:1 $\frac{1}{2}: 3$ at age 28 days is higher compared to strength at age 7 days (Fig. 5). The pattern is similar to other mix proportions, in which the strength increases with curing age. Possibly, this is owing to the fact that the rate of hydration of cement paste and mixing water in the cavities of the shells is lower than the rate of hydration of cement paste and mixing water in the surrounding paste, particularly at early age [50]. Similar observation has been documented by researchers elsewhere, Adewuyi \& Adegoke [33]. The decrease in the compression strength is due to factor such as the high-water absorption level by the crushed seashell aggregates and the low resistance to direct impact [62]. Concrete mixes 1:2:4 (Fig. 6) and 1:3:6 can achieve the minimum 28 day cube strength where the value is $21 \mathrm{~N} / \mathrm{mm}^{2}$ and $15 \mathrm{~N} / \mathrm{mm}^{2}$ with $35.4 \%$ and $42.5 \%$ substitution of periwinkle shell respectively [62]. According to Eziefula et al. [59], the increased water absorption of seashell aggregates, the elongated or flaky form of seashells, and the presence of organic materials all contribute to the loss in concrete strength. Based on Soneye et al. [54], material with high water absorption, by implication, promotes more water to be added to concrete during mixing, and the suggested intended grade will fail if the planned water is surpassed by a particular percentage. However, Ameh et al. [53] investigated the potential of fully and partly replacing the lateritic sand as fine aggregate and periwinkle shell as coarse aggregate. They found that $20 \%$ of replacements meet the optimum strength at age 7,14 and 28 days respectively. Further investigation needs to be conducted to determine the performance of concrete in terms of durability and fire resistance. This is due to many studies have shown that the properties that needed in a produce well-proportioned concrete mix include appropriate workability of fresh mixture, durability, economy, and fire resistance [63].

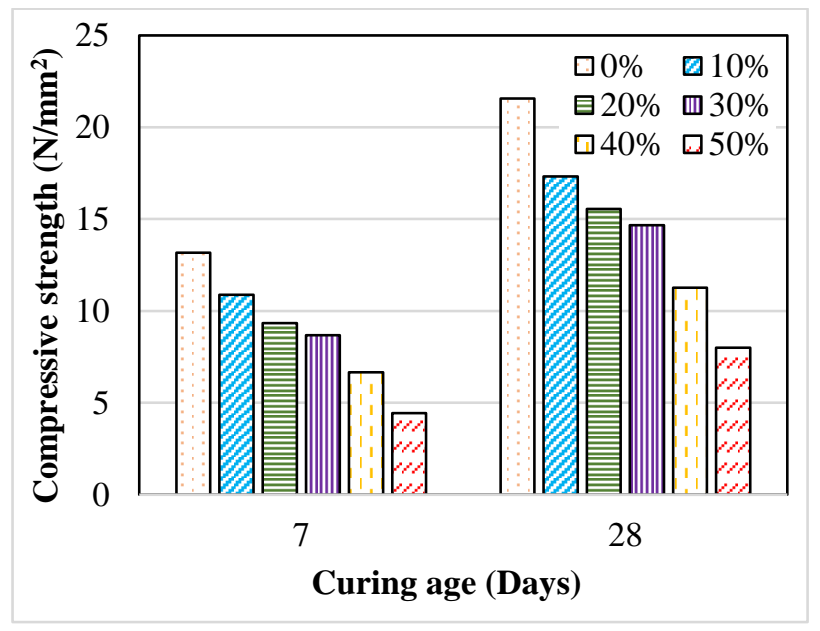

Figure 5. Compressive strength of mix proportion 1:1 $\frac{1}{2}: 3$ [50]

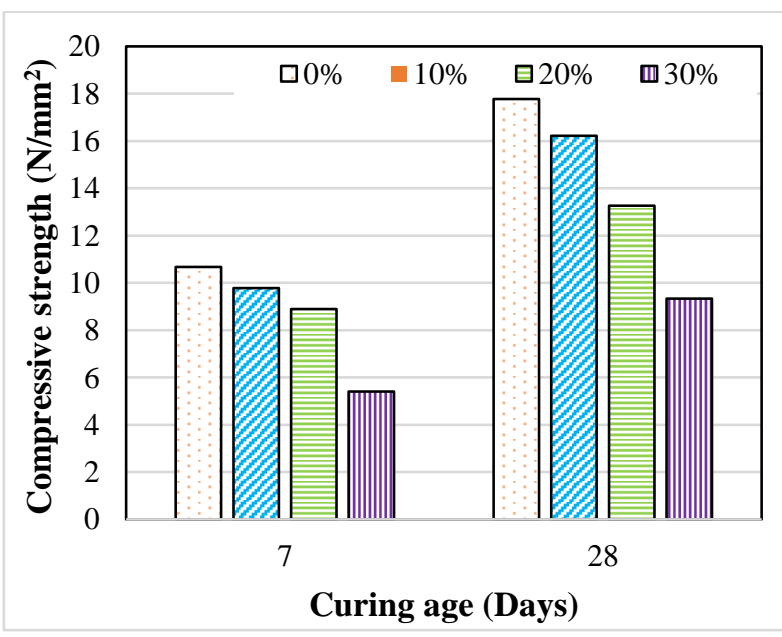

Figure 6. Compressive strength of mix proportion 1:2:4 [50]

\section{CONCLUSION}

This paper has discussed the properties of periwinkle shell as cement replacement and coarse aggregate replacement based on previous research. The incluson of periwinkle shell ash as partial cement replacement or coarse aggregate replacement affects concrete workability and compressive strength. Integraton of periwinkle shell ash forms concrete mixture with lower workability. Similarly, the use of periwinkle shell as coarse aggregate replacement also resulted in mix with lower slump value. In terms of strength, the use of this shell as coarse aggregate forms reduces concrete strength. However, the desired strength can still be achieved with appropriate replacement. Further research need to be carried out to investigate the effect of using this waste material on durability and fire resistance of various types of concrete. The approach of introducing periwinkle shell mixing ingredient in concrete also helps to reduce usage of natural resources become limited in the future. Besides, it can reduce the aquaculture waste that can contribute to environmental pollution if the waste is not treated. 


\section{ACKNOWLEDGEMENT}

The authors are grateful for the funding from Universiti Malaysia Pahang for supporting the study through the following financial grant PGRS 200385.

\section{REFERENCES}

[1] A. Kaish, T. C. Odimegwu, I. Zakaria, \& M. M. Abood. "Effects of different industrial waste materials as partial replacement of fine aggregate on strength and microstructure properties of concrete". J. Build. Eng., 35, 102092. 2021.

[2] G. H. Kusuma, J. Budidarmawan, \& A. Susilowati. "Impact of concrete quality on sustainability". Procedia Engineering, 125, 754-759. 2015.

[3] Current world population. Retrieved February 16, 2021, from https://www.worldometers.info/world-population/,2021.

[4] A. Obiekwe, Ubachukwu and O. Fidelis, Okafor: "Investigation of the supplementary cementitious potentials of oyster shell powder for ecofriendly and low-cost concrete” Electron. J. Geotech. Eng., (24.05), pp 1297-1306, 2019.

[5] S. Kumar Verma, C. Sheikhar Singla, G. Nadda, \& R. Kumar, "Development of sustainable concrete using silica fume and stone dust". Materials Today: Proceedings, 32, 882-887. 2020.

[6] S. N. Chinnu, S. N. Minnu, A. Bahurudeen, \& R. Senthilkumar. "Recycling of industrial and agricultural wastes as alternative coarse aggregates: A step towards cleaner production of concrete”. Constr Build Mater., 287, 123056. 2021.

[7] S. C. Bostanci. "Use of waste marble dust and recycled glass for sustainable concrete production". J. Clean. Prod., 251, 119785. 2020.

[8] M. A. Ashraf, M. J. Maah, I. Yusoff, A. Wajid, \& K. Mahmood. "Sand mining effects, causes and concerns: A case study from Bestari Jaya, Selangor, Peninsular Malaysia”. Sci Res Essays, 6(6). 2011.

[9] C. M. Grădinaru, R. Muntean, A. A. Șerbănoiu, V. Ciocan, \& A. Burlacu. "Sustainable development of human society in terms of natural depleting resources preservation using natural renewable raw materials in a novel ecological material production". Sustainability, 12(7), 2651. 2020.

[10] W.H. Langer, B.F. Arbogast. "Environmental impacts of mining natural aggregate”. In: Fabbri A.G., Gaál G., McCammon R.B. (eds) Deposit and Geoenvironmental Models for Resource Exploitation and Environmental Security. Nato Science Partnership Subseries: 2 (closed) (Series 2. Environment Security), vol 80. Springer, Dordrecht. 2002.

[11] R. Tomar, K. Kishore, H. Singh Parihar, \& N. A. Gupta. "Comprehensive study of waste coconut shell aggregate as raw material in concrete". Mater. Today: Proc. 2020.

[12] S. N. Shah, K. H. Mo, S. P. Yap, J. Yang, \& T. Ling. "Lightweight foamed concrete as a promising avenue for incorporating waste materials: A review”. Resour Conserv Recy, 164, 105103. 2021.

[13] N. Mohamad, K. Muthusamy, R. Embong, A. Kusbiantoro, \& M. H. Hashim. "Environmental impact of cement production and Solutions: A review". Mater. Today: Proc. 2021.

[14] C. Zhang, S. Yuan, D. Li. "Comprehensive control of the noise occupational hazard in cement plant". Procedia Eng., 43, pp. 186-190, 2012.

[15] S. Khan, N. Maheshwari, G. Aglave, \& R. Arora. "Experimental design of green concrete and assessing its suitability as a sustainable building material”. Mater. Today: Proc., 26, 1126-1130. 2020.

[16] K. H. Mo, U. J. Alengaram, M. Z. Jumaat, S. C. Lee, W. I. Goh, \& C. W. Yuen. "Recycling of seashell waste in concrete: A review". Constr Build Mater., 162, 751-764. 2018.

[17] R. A. Assaggaf, M. R. Ali, S. U. Al-Dulaijan, \& M. Maslehuddin. "Properties of concrete with untreated and treated crumb rubber: A review". J Mater Res Technol. 2021.

[18] B. A. Tayeh, M. W. Hasaniyah, A. Zeyad, \& M. O. Yusuf. "Properties of concrete containing recycled seashells as cement partial replacement: A review". J. Clean. Prod., 237, 117723. 2019.

[19] FAO. 2020. "The state of world fisheries and aquaculture". Sustainability in action. Rome. 2020.

[20] J. O. Afolayan, U. N. Wilson, \& B. Zaphaniah. "Effect of sisal fibre on partially replaced cement with Periwinkles Shell Ash (PSA) concrete". JASEM, 23(4), 715. 2019.

[21] L. O. Ettu, O. M. Ibearugbulem, J. C. Ezeh, \& U. C. Anya. "A reinvestigation of the prospects of using periwinkle shell as partial replacement for granite in concrete". Int. J. Eng. Sci., 2(3), 54-59. 2013.

[22] G. O. Bamigboye, A. T. Nworgu, A. O. Odetoyan, M. Kareem, D. O. Enabulele, \& D. E. Bassey. "Sustainable use of seashells as binder in Concrete production: Prospect and challenges". J. Build. Eng., 34, 101864. 2021.

[23] S. H. Saharudin, J. H. Shariffuddin, N. I. Nordin, \& A. Ismail. "Effect of aging time in the synthesis of biogenic hydroxyapatite derived from cockle shell”. Mater. Today: Proc., 19, 1208-1215. 2019.

[24] Y., A. Hou, Shavandi, A. Carne, A.A. Bekhit, T.B. Ng, R.C.F. Cheung \& A.E.A. Bekhit. "Marine shells: Potential opportunities for extraction of functional and health-promoting materials". Crit Rev Env Sci Tec. 46, 1047-1116, 2016.

[25] B. Safi, M. Saidi, A. Daoui, A. Bellal, A. Mechekak, \& K. Toumi. "The use of seashells as a fine aggregate (by sand substitution) in self-compacting mortar (SCM)". Constr Build Mater., 78, 430-438. 2015.

[26] E.-I. Yang, S.-T.Yi, \& Y.-M. Leem. "Effect of oyster shell substituted for fine aggregate on concrete characteristics: Part I. Fundamental properties". Cem Concr Res, 35(11), 2175-2182. 2005. 
[27] M. Olivia, R. Oktaviani, \& Ismeddiyanto. "Properties of concrete containing ground waste cockle and clam seashells". Procedia Eng., 171, 658-663. 2017.

[28] E.-I. Yang, M.-Y. Kim, H.-G. Park, \& S.-T. Yib. "Effect of partial replacement of sand with dry oyster shell on the long-term performance of concrete". Constr Build Mater., 24(5), 758-765. 2010.

[29] I. E. Ekop, K. J. Simonyan, \& U. N. Onwuka. "Effects of processing factors and conditions on the cracking efficiency of Tympanotonus fuscatus and pachymelania Aurita periwinkles: Response surface approach”. J. Sci. Food Agric., 3, 100094. 2021.

[30] D. Dahiru, U. Yusuf, \& N. Paul. "Characteristics of concrete produced with periwinkle and palm kernel shells as aggregates". FUTY Journal of the Environment, 12(1). 2018.

[31] K. E. Ogundipe, B. F. Ogunbayo, O. M. Olofinnade, L. M. Amusan, \& C. O. Aigbavboa. "Affordable housing issue: Experimental investigation on properties of eco-friendly lightweight concrete produced from incorporating periwinkle and palm kernel shells". RINENG, 9, 100193. 2021.

[32] O. I. Agbede, \& J. Manasseh. "Suitability of periwinkle shell as partial replacement for river gravel in concrete". LEJPT, (15). 2009.

[33] A. Adewuyi, \& T. Adegoke. "Exploratory study of periwinkle shells as coarse aggregates in concrete works". JEAS, 3(6). 2008.

[34] J. K. Prusty, \& S. K. Patro. "Properties of fresh and hardened concrete using agro-waste as partial replacement of coarse aggregate - a review". Constr Build Mater., 82, 101-113. 2015.

[35] F. A. Olutoge, O. M. Okeyinka, \& O. S. Olaniyan. "Assessment of The suitability of Periwinkle Shell Ash (PSA) as partial replacement for ordinary portland cement (opc) in concrete". IJRRAS, 10(3). 2012.

[36] A. A. Umoh, \& K. O. Olusola. "Compressive strength and static modulus of elasticity of periwinkle shell ash blended cement concrete". IJSCET, 3(2). 2012.

[37] R. K. Etim, I. C. Attah, \& O. B. Bassey. “Assessment of periwinkle shell ash blended cement concrete incrude oil polluted environment”. FTSTJ, 2(2), 879-885. 2017.

[38] U. D. Offiong, \& G. E. Akpan. "Assessment of physico-chemical properties of periwinkle shell ash as partial replacement for cement in concrete". IJSES, 1(7), 33-36. 2017.

[39] I. C. Attah, R. K. Etim, \& D. U. Ekpo. "Behaviour of periwinkle shell ash blended cement concrete in sulphuric acid environment”. NIJOTECH, 37(2), 315-321. 2018.

[40] Y. Zhang, D. Chen, Y. Liang, K. Qu, K. Lu, S. Chen, \& M. Kong. "Study on engineering properties of foam concrete containing waste seashell”. Constr Build Mater., 260, 119896. 2020.

[41] W. A. Wan Mohammad, N. H. Othman, M. H. Wan Ibrahim, M. A. Rahim, Sx. Shahidan, \& R. A. Rahman. "A review on seashells ash as partial cement replacement”. IOP Conf. Ser.: Mater. Sci. Eng., 271, 012059. 2017.

[42] B. A. Tayeh, M. W. Hasaniyah, A. M. Zeyad, M. M. Awad, A. Alaskar, A. M. Mohamed, \& R. Alyousef. "Durability and mechanical properties of seashell partially-replaced cement". J. Build. Eng., 31, 101328. 2020.

[43] A.S. Wagh. "Chemically bonded phosphate ceramics. twenty-first century materials with diverse applications". (second ed.), $\mathrm{m}$ Elsevier Publishers, p. 422. 2016.

[44] BS EN 197 - 1. Cement Composition, Specification and Conformity Criteria for Common Cements. London, British Standard Institution. 2009.

[45] S. O. Odeyemi, R. Abdulwahab, A. G. Adeniyi, \& O. D. Atoyebi. "Physical and mechanical properties of cement-bonded particle board produced from African balsam tree (Populous Balsamifera) and periwinkle shell residues". RINENG, 6, 100126. 2020.

[46] M. S. Shetty, \& A. K. Jain. "Concrete technology theory and practice". S. Chand Publishing. 2005.

[47] M. Olivia, A. A. Mifshella, \& L. Darmayanti. "Mechanical properties of seashell concrete". Procedia Eng, 125, 760-764. 2015.

[48] N. Razali, R. N. F. R. Aris, N. Razali, \& K. F. Pa'ee. "Revalorization of aquaculture waste: The performance of calcined mussel shells as partial cement replacement". ICERT. 2017.

[49] R. Y. Bharathi, S. Subhashini, T. Manvitha, \& S. H. Lessly. "Experimental study on partial replacement of coarse aggregate by seashell \& partial replacement of cement by flyash". IJLRET, 2(3). 2016.

[50] F. Falade. "An investigation of periwinkle shells as coarse aggregate in concrete". Build Environ, 30(4), 5 73-577. 1995.

[51] J. Osarenmwinda, \& A. Awaro. "The potential use of periwinkle shell as coarse aggregate for concrete". Adv Mat Res, 62-64, 39-43. 2009.

[52] F. Falade, E. E. Ikponmwosa, \& N. I. Ojediran. "Behaviour of lightweight concrete containing periwinkle shells at elevated temperature". JESTEC, 5(4). 2010.

[53] O. J. Ameh, I. T. Afuye, \& L. M. Amusan. "Prospect of lateritic sand and periwinkle shell as aggregates in concrete". AJET, 4(2). 2014.

[54] T. Soneye, A. N. Ede, G. O. Bamigboye, \& D. O. Olukanni. "The study of periwinkle shells as fine and coarse aggregate in concrete works". CU-ICADI. 2016.

[55] U. G. Eziefula, H. E. Opara, \& C. U. Anya. "Mechanical properties of palm kernel shell concrete in comparison with periwinkle shell concrete”. Malays. J. Civ. Eng, 29(1), 1-14. 2017. 
[56] D. H. Nguyen, M. Boutouil, N. Sebaibi, L.Leleyter, \& F. Baraud. "Valorization of seashell by-products in pervious concrete pavers". Constr Build Mater, 49, 151-160. 2013.

[57] D. H. Nguyen, M. Boutouil, N. Sebaibi, F. Baraud, \& L. Leleyter. "Durability of pervious concrete using crushed seashells". Constr Build Mater. 135, 137-150. 2017.

[58] A.M. Neville, and J.J. Brooks. Concrete Technology (2nd ed.). Essex: Pearson Education. 2010.

[59] U. G. Eziefula, J. C. Ezeh, \& B. I. Eziefula. "Properties of seashell aggregate concrete: A review". Constr Build Mater, 192, 287-300. 2018.

[60] ASTM C 127-88. Standard Test Method for: Specific Gravity and Absorption of Coarse Aggregate. 2001.

[61] C. Martínez-García, B. González-Fonteboa, F. Martínez-Abella, \& D. Carro- López. "Performance of mussel shell as aggregate in plain concrete". Constr Build Mater, 139, 570-583. 2017.

[62] G. O. Bamigboye, O. Okara, D. E. Bassey, K. J. Jolayemi, \& D. Ajimalofin. "The use of Senilia senilis seashells as a substitute for coarse aggregate in eco-friendly concrete”. J. Build. Eng., 32, 101811. 2020.

[63] C. P. Ukpaka, G. I. Okochi. "Production of cement from mixture of palm kernel and periwinkle shell". IJE. 15, 166-179. 2018. 